Joumal of Organometallic Chemistry, 438 (1992) 1-10

Elsevier Sequoia S.A., Lausanne

JOM 22814

\title{
Solid-state and solution structures of three lithiumsulfinimidamides: identification of two distinct structural types
}

\author{
Frank T. Edelmann, Friederich Knösel, Frank Pauer, Dietmar Stalke \\ Institut für Anorganische Chemie der Universität Göttingen, Tammannstraße 4, \\ W-3400 Göttingen (Germany)
}

\section{and Walter Bauer}

Institut für Organische Chemie der Universität Erlangen-Nürmberg, Henkestraße 42, W-8520 Erlangen (Germany)

(Received March 16, 1992)

\begin{abstract}
The bidentate sulfinimidamide ligand has almost the same bulk as the cyclopentadienyl ligand. Two distinct structural types of highly reactive lithium sulfinimidamides, commonly used reagents, have been identified by $\mathrm{X}$-ray diffraction and solution NMR studies. In the crystalline state the diethyl ether adducts $\left[\left(\mathrm{Me}_{3} \mathrm{SiN}\right)_{2} \mathrm{~S}\left(\mathrm{C}_{6} \mathrm{H}_{5}\right) \mathrm{Li}\right]_{2} \cdot \mathrm{Et}_{2} \mathrm{O}$ and $\left[\left(\mathrm{Me}_{3} \mathrm{SiN}\right)\left({ }^{\mathrm{t}} \mathrm{BuN}\right) \mathrm{S}\left(\mathrm{C}_{6} \mathrm{H}_{5}\right) \mathrm{Li}\right]_{2} \cdot \mathrm{Et}_{2} \mathrm{O}$ adopt a twisted tricyclic structure with both a four coordinate and a three coordinate lithium atom in the same aggregate. The ${ }^{1} \mathrm{H}$ NMR spectra at various temperatures and the low temperature phase-sensitive ${ }^{6} \mathrm{Li},{ }^{1} \mathrm{H}$ HOESY NMR experiment show that this structure is essentially retained in solution. The smaller bulk and higher polarity of tetrahydrofuran compared with diethyl ether results in the coordination of two solvent molecules to give $\left[\left(\mathrm{Me}_{3} \mathrm{SiN}\right)_{2} \mathrm{~S}\left(\mathrm{C}_{6} \mathrm{H}_{5}\right) \mathrm{Li} \cdot \mathrm{THF}\right]_{2}$, which has a centrosymmetric stair-shaped tricyclic structure consisting of three fused four-membered rings.
\end{abstract}

\section{Introduction}

Alkali metal sulfinimidamides are used in Main Group and transition metal chemistry to introduce the bidentate sulfinimidamide ligand, which has almost the same bulk as the cyclopentadienyl ligand [1-5]. Our "tailor made" alkali metal organosulfinimidamides show three structural classes [6]:

Correspondence to: Dr. D. Stalke. 
<smiles>[R]N1N2[Si]([R])N([R])[Si]1([R])N([R])[SiH]2OCC</smiles>

a<smiles>[R]N1N2[SiH]([R])N([R])[Si]1([R])N([R])[Si]2([R])[R]</smiles>

b<smiles>[R]N1[SiH]N([R])[SiH]([R])N([R])[SiH]([R])N1[R]</smiles>

c

Two examples of class a are presented in this paper: in $\left[\left(\mathrm{Me}_{3} \mathrm{SiN}\right)_{2} \mathrm{~S}\left(\mathrm{C}_{6} \mathrm{H}_{5}\right) \mathrm{Li}\right]_{2}$ - $\mathrm{Et}_{2} \mathrm{O}(1)$ and in $\left.\left[\left(\mathrm{Me}_{3} \mathrm{SiN}\right){ }^{\mathrm{t}} \mathrm{BuN}\right) \mathrm{S}\left(\mathrm{C}_{6} \mathrm{H}_{5}\right) \mathrm{Li}\right]_{2} \cdot \mathrm{Et}_{2} \mathrm{O}$ (2) two $\mathrm{SN}_{2} \mathrm{Li}$ four membered rings are fused on adjacent sides of the central $\mathrm{Li}_{2} \mathrm{~N}_{2}$ four membered ring to give a twisted tricyclic structure with both lithium atoms and the oxygen atom of the single coordinated ether molecule on a two fold axis. The tricycle in $\mathbf{b}$, illustrated by the structure of $\left[\left(\mathrm{Me}_{3} \mathrm{SiN}\right)_{2} \mathrm{~S}\left(\mathrm{C}_{6} \mathrm{H}_{5}\right) \mathrm{Li} \cdot \mathrm{THF}\right]_{2}(3)$ is formed from two $\mathrm{SN}_{2} \mathrm{Li}$ four membered rings on opposite sides of the central $\mathrm{Li}_{2} \mathrm{~N}_{2}$ ring. This stair shaped tricycle and the eight membered ring in $c$ have $\mathrm{C}_{i}$ symmetry. It is noteworthy that the lithium atoms in $\mathbf{c}\left(\mathrm{R}^{1}={ }^{\mathrm{t}} \mathrm{Bu}, \mathrm{R}^{2}=\mathrm{SiMe}_{3}, \mathrm{R}^{3}=\mathrm{SiMe}_{3},{ }^{\mathrm{t}} \mathrm{Bu}\right)$ [6] are not coordinated by donor molecules, even though the synthesis was carried out in diethyl ether. In addition to these three classes we have studied the "ate" type structure of $\left[\mathrm{Li}\left(\left(\mathrm{Me}_{3} \mathrm{SiN}\right)_{2}\left(\mathrm{C}_{6} \mathrm{H}_{5}\right) \mathrm{S}\right)_{2}\right]^{-}\left[\mathrm{Li}\left(12 \text {-crown-4) }{ }_{2}\right]^{+}\right.$by X-ray structural studies and ${ }^{7} \mathrm{Li}$ solid state NMR experiments [7].

\section{Results and discussion}

The sulfur diimides $\mathrm{Me}_{2} \mathrm{SiN}=\mathrm{S}=\mathrm{NR}\left(1,3: \mathrm{R}=\mathrm{SiMe}_{3} ; 2: \mathrm{R}={ }^{\mathrm{t}} \mathrm{Bu}\right)$ react with phenyllithium in diethyl ether or tetrahydrofuran (THF) at $-50^{\circ} \mathrm{C}$. As shown by NMR spectroscopy in solution, and by the X-ray structures, either half a molecule of diethyl ether or a whole molecule of THF is coordinated to a single unit of lithium sulfinimidamide.

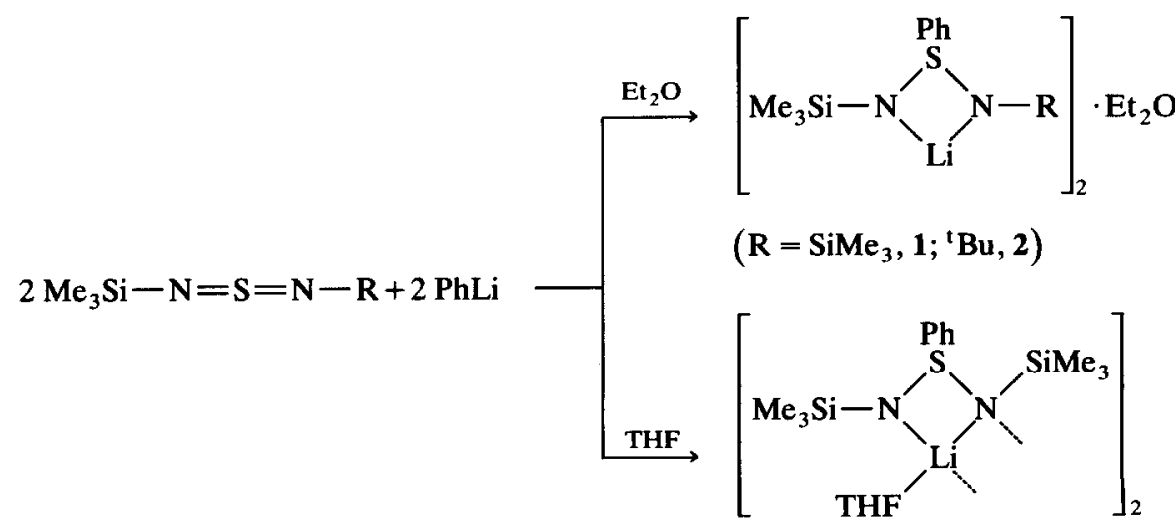




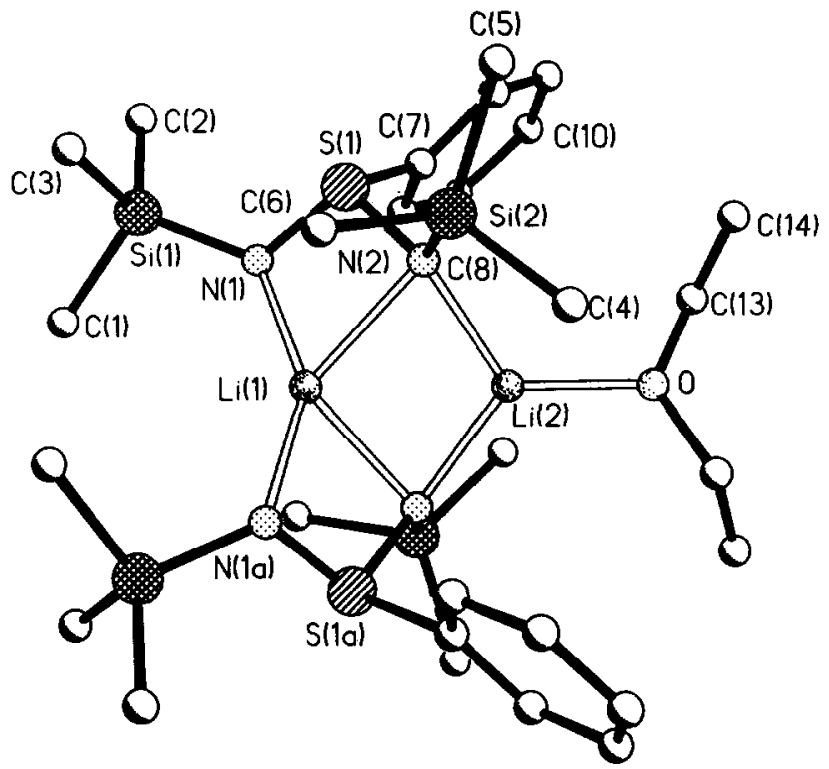

Fig. 1. The structure of 1 in the solid state.

\section{Crystal structures of 1 and 2}

The most striking feature of the structures of 1 (Fig. 1) and 2 (Fig. 2) is the inequivalence of the coordination sphere of the lithium atoms. The $\mathrm{Li}(1)$ atom is four coordinated by the four nitrogen atoms of the dimer, whereas $\mathrm{Li}(2)$ is only three coordinated by two nitrogen atoms and the oxygen atom of the single ether molecule. The presence of different coordination numbers for lithium in the same

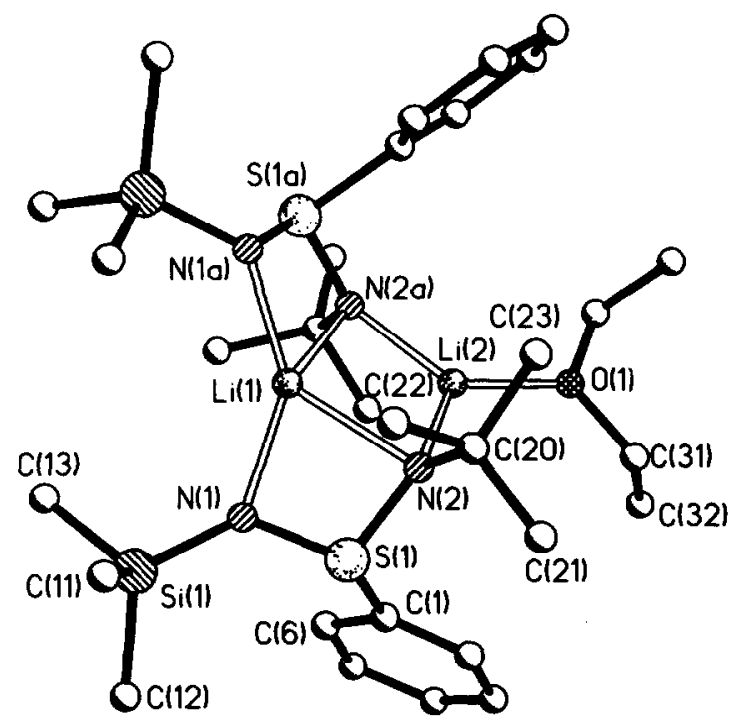

Fig. 2. The structure of 2 in the solid state. 


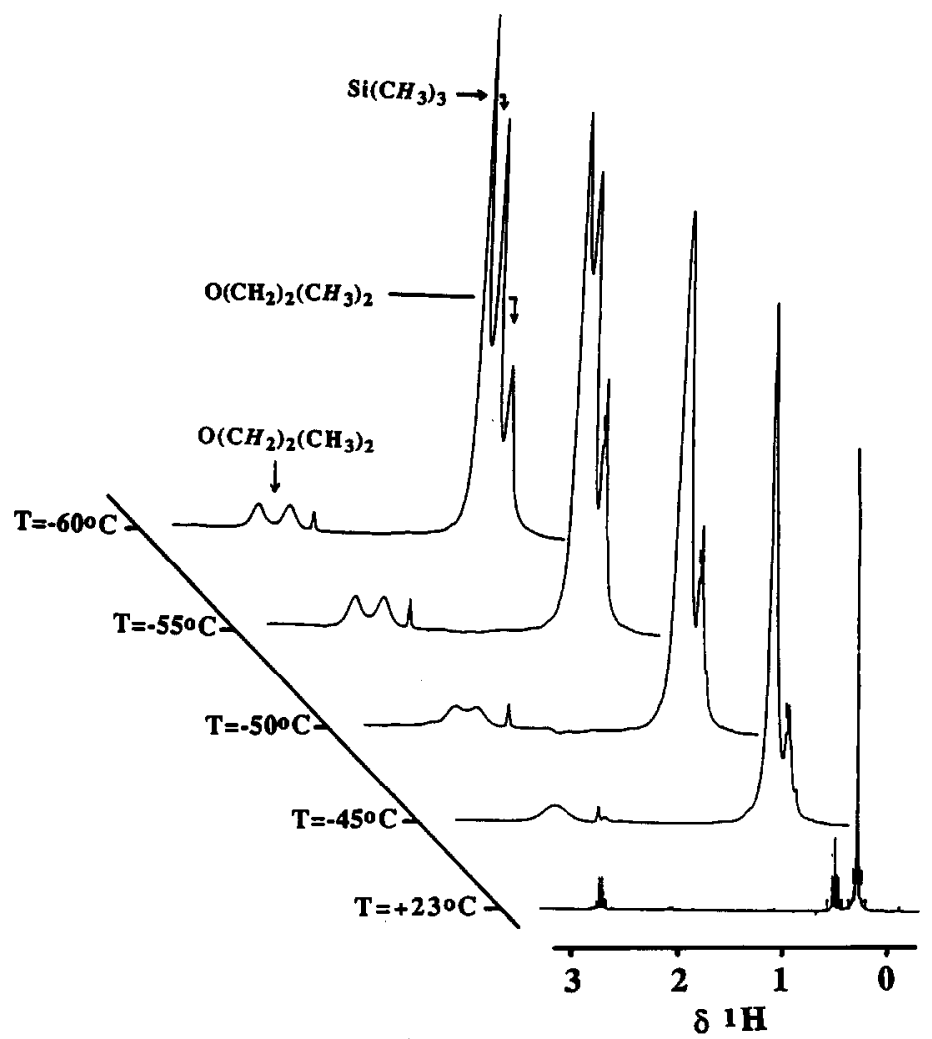

Fig. 3. The $\delta$ 0-3 region in the ${ }^{1} \mathrm{H}$ NMR spectrum of 1 at various temperatures.

molecule is relatively rare [8-11], but the structure of $\left[\mathrm{Me}_{2} \mathrm{Si}\left(\mathrm{O}^{t} \mathrm{Bu}\right)\left(\mathrm{N}^{t} \mathrm{Bu}\right) \mathrm{Li}\right]_{2}$. THF [12] is an isotype of 1 and 2 . In $\left[\left(\left(\mathrm{Me}_{3} \mathrm{SiN}\right)(\mathrm{RN})\left(\mathrm{C}_{6} \mathrm{H}_{5}\right) \mathrm{S}\right) \mathrm{Li}\right]_{2} \cdot \mathrm{Et}_{2} \mathrm{O}(\mathbf{1}$ : $\left.\mathrm{R}=\mathrm{SiMe}_{3} ; 2: \mathrm{R}={ }^{\mathrm{t}} \mathrm{Bu}\right) \mathrm{Li}(1)$ is strongly coordinated to $\mathrm{N}(1)(\mathrm{Li}(1)-\mathrm{N}(1): 199.4(3)$ in 1 and 198.3(8) pm in 2) but loosely coordinated to $\mathrm{N}(2)(\mathrm{Li}(1)-\mathrm{N}(2): 224.5(5)$ in 1 and 223.4(13) pm in 2). The $\mathrm{Li}(2)-\mathrm{N}(2)$ distances are 203.3(5) in 1 and 200.5(11) $\mathrm{pm}$ in 2. The average $\mathrm{S}-\mathrm{N}$ distance over all three structures (Table 2) is $161.2 \mathrm{pm}$, hence $7.6 \mathrm{pm}$ longer than the $\mathrm{S}=\mathrm{N}$ double bond in the $\left(\mathrm{Me}_{3} \mathrm{SiN}\right)_{2} \mathrm{~S}$ sulfurdiimide [13]. It is noteworthy that in 2 the quaternary nitrogen atom $N(2)$ is preferentially substituted by ' $\mathrm{Bu}$, rather than $\mathrm{SiMe}_{3}$, in spite of its slightly larger steric effect.

\section{NMR investigations of 1 and 2}

If the structure of 1 and $\mathbf{2}$ in solution is identical with the solid state structure, then two resonances would be expected in the Li NMR spectra of both 1 and 2, and two for the $\mathrm{SiMe}_{3}$ groups in the ${ }^{1} \mathrm{H}$ NMR spectrum of 1 [8]. In toluene-d $d_{8}$ at $-60^{\circ} \mathrm{C}$, the ${ }^{7} \mathrm{Li}$ NMR spectra of 1 and 2 do indeed show two resonances in $1: 1$ ratio; this must be due to different chemical environments of $\mathrm{Li}(1)$ and $\mathrm{Li}(2)$. The results of a variable temperature ${ }^{1} \mathrm{H}$ NMR experiment on 1 are shown in Fig. 3. At $-50^{\circ} \mathrm{C}$, the signals of the chemically non-equivalent $\mathrm{SiMe}_{3}$ groups of 1 are not resolved, although the $\mathrm{O}\left(\mathrm{CH}_{2}\right)_{2}\left(\mathrm{CH}_{3}\right)_{2}$ signal shows two resonances at 2.40 and $2.60 \mathrm{ppm}$ due to diastereotopy. Thus, on the NMR time scale the diethyl ether 
c)
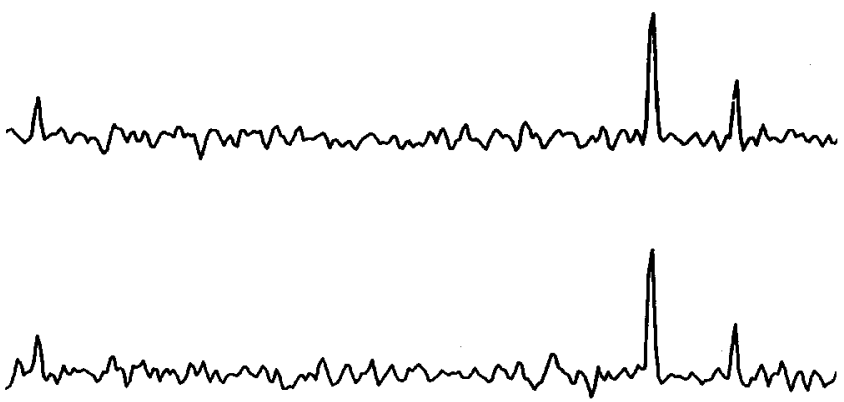

b)

a)
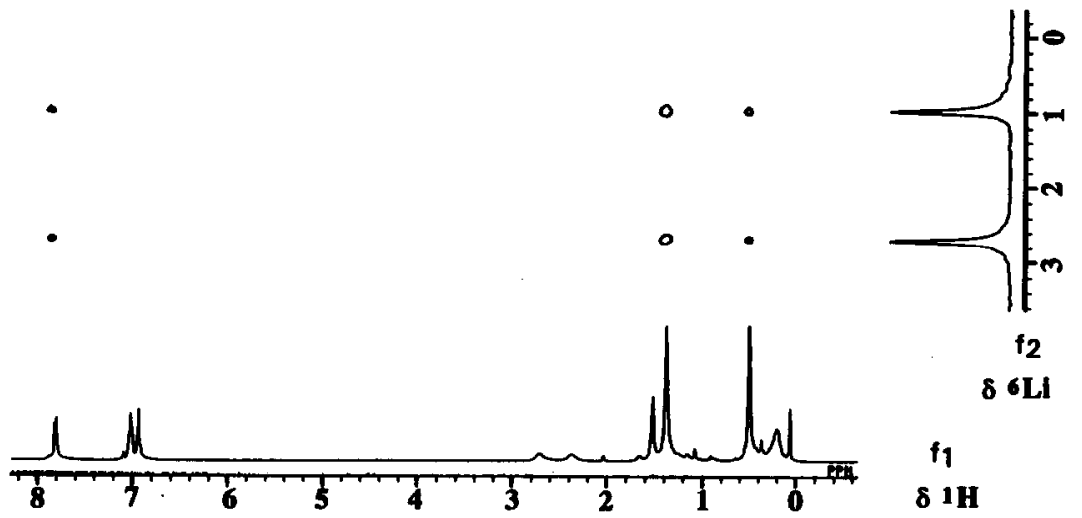

$86 \mathrm{LI}$

$f_{1}$

$\delta \mathbf{1 H}$

Fig. 4. Phase sensitive ${ }^{6} \mathrm{Li},{ }^{1} \mathrm{H}$ HOESY spectrum of 2 in toluene- $d_{8},-70^{\circ} \mathrm{C}$; mixing time $T_{\mathrm{m}}=1.8 \mathrm{sec}$. a) contour plot; b), c), $f_{1}$ cross sections at $\delta^{6} \mathrm{Li}=1.0$ and $2.35 \mathrm{ppm}$.

molecule must be tightly attached to the chiral lithium sulfinimidamide moiety. Upon further cooling to $-60^{\circ} \mathrm{C}$ the coalesced signal of the $\mathrm{SiMe}_{3}$ groups also show splitting due to diasterotopicity, as would be expected from the solid state structure $(\delta=0.40$ and $0.51 \mathrm{ppm})$. This splitting arises from the fact that one $\mathrm{SiMe}_{3}$ group bound to a tertiary and the other to a quaternary nitrogen atom (Fig. 1). This indicates that the different coordinations of $\mathrm{Li}(1) / \mathrm{Li}(2)$ and $\mathrm{N}(1) / \mathrm{N}(2)$ must be maintained, unlike those in the isotype $\left[\mathrm{Me}_{2} \mathrm{Si}\left(\mathrm{O}^{\mathrm{t}} \mathrm{Bu}\right)\left(\mathrm{N}^{\mathrm{t}} \mathrm{Bu}\right) \mathrm{Li}\right]_{2} \cdot \mathrm{THF}$ [12].

In order to assign the two resonances in the ${ }^{7} \mathrm{Li}$ NMR spectrum we synthesized the ${ }^{6} \mathrm{Li}$-enriched derivative $\left[\left(\left(\mathrm{Me}_{3} \mathrm{SiN}\right)\left({ }^{\mathrm{t}} \mathrm{BuN}\right)\left(\mathrm{C}_{6} \mathrm{H}_{5}\right) \mathrm{S}\right) \mathrm{Li}\right]_{2} \cdot \mathrm{Et}_{2} \mathrm{O}, 2$, and examined the ${ }^{1} \mathrm{H}$ HOESY NMR spectrum (Fig. 4) [14-16]. Unfortunately, even at the low temperature employed to generate Fig. $4\left(-70^{\circ} \mathrm{C}\right)$ there must be moderate chemical exchange of the two lithium sites. During the mixing period of the HOESY pulse sequence $\left(T_{m}=1.8 \mathrm{sec}\right.$ in Fig. 4) the chemical environments of $\mathrm{Li}(1)$ and $\mathrm{Li}(2)$ obviously become averaged. Thus, cross peaks appear at identical ${ }^{1} \mathrm{H}$ chemical shifts for both ${ }^{6} \mathrm{Li}$ signals. These include the expected ${ }^{1} \mathrm{H}$ positions, i.e. the $\mathrm{Si}\left(\mathrm{CH}_{3}\right)_{3}, \mathrm{C}\left(\mathrm{CH}_{3}\right)_{3}$, and the ortho-H resonance lines.

Turning to the crystal structure of 3 we see that the use of THF as a donor rather than diethyl ether, gives rise to a quite different structural type. The higher polarity of THF $(\mu=1.63 \mathrm{D})$ and its smaller steric requirement compared to that of diethyl ether $(\mu=1.15 \mathrm{D})$ allows incorporation of two THF molecules into the 


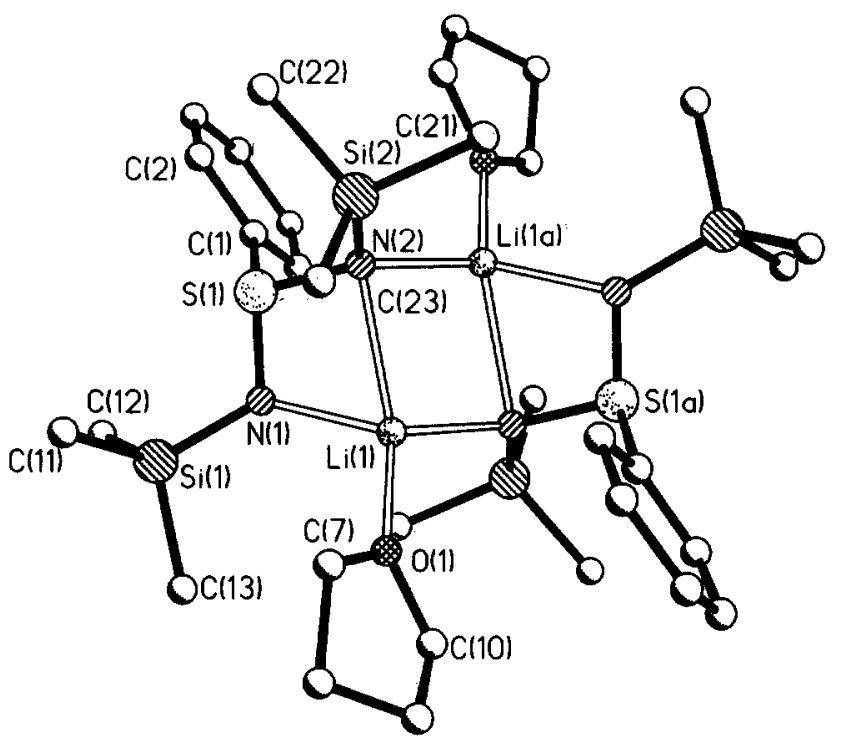

Fig. 5. The structure of 3 in the solid state.

dimer, to give a centrosymmetric structure (Fig. 5). Like the other alkali metal sulfinimidamides we have investigated, this lithium derivative also forms a stairshaped tricycle [6]. However, the metal $\cdots$ phenyl interaction, observed in the other derivatives, is not present here. The $\mathrm{Li}(1)$-ring centre distance is $431.3 \mathrm{pm}$, i.e. $45 \mathrm{pm}$ and $76.2 \mathrm{pm}$ longer than the corresponding distance in the sodium and caesium derivatives, respectively. The harder lithium metal does not interact with the $\pi$ system of the ring as do the softer alkali metals, $\mathrm{Na}$ to Cs. The normal of the $\mathrm{Li}_{2} \mathrm{~N}_{2}$ plane intersects that of the LiNSN plane at an angle of $144.0^{\circ}$. The donor capacity of the $\mathrm{Me}_{2} \mathrm{Si}\left(\mathrm{O}^{t} \mathrm{Bu}\right)\left(\mathrm{N}^{t} \mathrm{Bu}\right)$ ligand in a dimer is obviously greater than that of the $\left(\mathrm{Me}_{3} \mathrm{SiN}\right)_{2} \mathrm{~S}\left(\mathrm{C}_{6} \mathrm{H}_{5}\right)$ ligand. The latter coordinates two THF molecules per dimer and the former coordinates only one.

\section{Experimental section}

All experiments were carried out under dry argon with strict exclusion of air and moisture.

NMR spectra were recorded on Bruker AM250 (Fig. 3) and JEOL GX400 (Fig. 4) spectrometers, respectively. Solutions of $2(\mathrm{ca} .10 \%)$ in toluene- $d_{8}$ and in $\mathrm{CDCl}_{3}$ $\left(2,{ }^{1} \mathrm{H}\right.$ and $\left.{ }^{13} \mathrm{C}\right)$ were employed. Chemical shifts are referenced to TMS $\left({ }^{1} \mathrm{H},{ }^{13} \mathrm{C}\right.$, ${ }^{29} \mathrm{Si}$ ) and external $\mathrm{LiCl}$ in $\mathrm{D}_{2} \mathrm{O}\left({ }^{6,7} \mathrm{Li}\right)$. Selected parameters of the phase sensitive ${ }^{6} \mathrm{Li},{ }^{1} \mathrm{H}$ HOESY experiment (Fig. 4) were: $T=-70^{\circ} \mathrm{C}$, spectral widths $400 \mathrm{~Hz}\left(f_{2}\right)$ and $3584 \mathrm{~Hz}\left(f_{1}\right), 512$ data points in $t_{2}, 128$ increments in $t_{1}$, zero filled to 256 data points. $90^{\circ}$ pulse widths $24 \mu \mathrm{s}\left({ }^{6} \mathrm{Li}\right)$ and $28 \mu \mathrm{s}\left({ }^{1} \mathrm{H}\right), 10 \mathrm{~mm}$ multinuclear probe head, $5 \mathrm{~mm}$ sample tube, inter-pulse delay $3.2 \mathrm{sec}$, exponential line broadening in $f_{2}$, Gaussian apodization in $f_{1} ; 7 \mathrm{~h}$ spectrometer time.

Preparations of compounds 1 and 2: A solution of $20 \mathrm{mmol} \mathrm{Me}{ }_{3} \mathrm{SiN}=\mathrm{S}=\mathrm{NR}$ (1: $\mathrm{R}=\mathrm{SiMe}_{3} ; 2: \mathrm{R}={ }^{\mathrm{t}} \mathrm{Bu}$ ) in $50 \mathrm{ml}$ hexane was cooled to $-50^{\circ} \mathrm{C}$ and $10 \mathrm{ml} \mathrm{C}_{6} \mathrm{H}_{5} \mathrm{Li}$ 
(2 $M$ solution in $\mathrm{Et}_{2} \mathrm{O} /$ cyclohexane) added. The mixture was subsequently refluxed for $1 \mathrm{~h}$. After 2 days at room temperature, pale yellow crystals were obtained.

Preparation of compound 3: A solution of $10 \mathrm{mmol}\left(\mathrm{Me}_{3} \mathrm{SiN}\right)_{2} \mathrm{~S}$ in $20 \mathrm{ml}$ hexane was cooled to $-50^{\circ} \mathrm{C}$ and $5 \mathrm{ml} \mathrm{C}_{6} \mathrm{H}_{5} \mathrm{Li}$ ( $2 \mathrm{M}$ solution in ether/cyclohexane) was added. After the mixture had warmed up to room temperature it was refluxed for $1 \mathrm{~h}$. The solvent was removed under vacuum, the residue dissolved in a mixture of $20 \mathrm{ml}$ hexane and $3 \mathrm{~g} \mathrm{(42} \mathrm{mmol)} \mathrm{of} \mathrm{THF.} \mathrm{Crystals} \mathrm{were} \mathrm{separated} \mathrm{from} \mathrm{this}$ solution.

Bis(lithium- $N, N^{\prime}$-bis(trimethylsilyl)-S-phenyl-sulfinimidamide)-monoetherate (1): M.p. $160^{\circ} \mathrm{C}$. Yield $6.1 \mathrm{~g}(94 \%)$. ${ }^{1} \mathrm{H}$ NMR: $\delta=0.28\left(\mathrm{~s}, \mathrm{Si}\left(\mathrm{CH}_{3}\right)_{3}\right) ; 0.49(\mathrm{t}$, $\left.\mathrm{O}\left(\mathrm{CH}_{2}\right)_{2}\left(\mathrm{CH}_{3}\right)_{2}\right) ; 2.73\left(\mathrm{q}, \mathrm{O}\left(\mathrm{CH}_{2}\right)_{2}\left(\mathrm{CH}_{3}\right)_{2}\right) ; 6.97-7.73\left(\mathrm{~m}, \mathrm{C}_{6} \mathrm{H}_{5}\right) .{ }^{13} \mathrm{C}$ NMR:

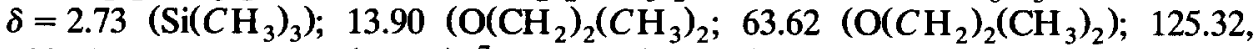
$128.49,137.40,155.76\left(C_{6} \mathrm{H}_{5}\right) .{ }^{7} \mathrm{Li}$ NMR $\left(-60^{\circ} \mathrm{C}\right): \delta=1.2,2.7$ (s, ratio $\left.1: 1\right)$.

Bis(lithium- $N$-trimethylsilyl- $N$ '-tert-butyl-S-phenyl-sulfinimidamide)-monoetherate (2): Yield $5.9 \mathrm{~g}(95 \%)$. ${ }^{1} \mathrm{H}$ NMR: $\delta=0.281\left(\mathrm{~s}, \mathrm{Si}\left(\mathrm{CH}_{3}\right)_{3}\right) ; 1.21(\mathrm{t}$, $\mathrm{O}\left(\mathrm{CH}_{2}\right)_{2}\left(\mathrm{CH}_{3}\right)_{2} ; 1.39\left(\mathrm{~s},{ }^{\mathrm{t}} \mathrm{C}_{4} \mathrm{H}_{9}\right) ; 3.48\left(\mathrm{q}, \mathrm{O}\left(\mathrm{CH}_{2}\right)_{2}\left(\mathrm{CH}_{3}\right)_{2}\right) ; 7.24-7.75\left(\mathrm{~m}, \mathrm{C}_{6} \mathrm{H}_{5}\right)$.

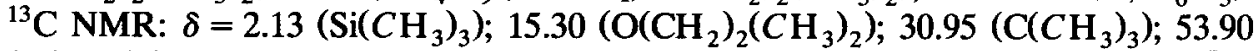

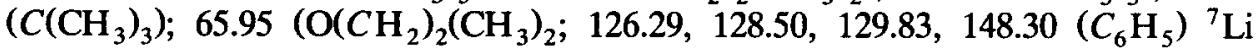
NMR $\left(-70^{\circ} \mathrm{C}\right): \delta=1.0,2.75$ (s, ratio $\left.1: 1\right) .{ }^{29} \mathrm{Si} \mathrm{NMR:} \delta=-8.6$ (s).

Table 1

Crystallographic data for 1-3

\begin{tabular}{|c|c|c|c|}
\hline & 1 & 2 & 3 \\
\hline $\begin{array}{l}\text { Empirical formula } \\
\text { Formula weight }\end{array}$ & $\begin{array}{l}\mathrm{C}_{28} \mathrm{H}_{56} \mathrm{Li}_{2} \mathrm{~N}_{4} \mathrm{OS}_{2} \mathrm{Si}_{4} \\
6555.12\end{array}$ & $\begin{array}{l}\mathrm{C}_{30} \mathrm{H}_{56} \mathrm{Li}_{2} \mathrm{~N}_{4} \mathrm{OS}_{2} \mathrm{Si}_{2} \\
623.0\end{array}$ & $\begin{array}{l}\mathrm{C}_{32} \mathrm{H}_{62} \mathrm{Li}_{2} \mathrm{~N}_{4} \mathrm{O}_{2} \mathrm{~S}_{2} \mathrm{Si}_{4} \\
725.3\end{array}$ \\
\hline Data collection at $T\left({ }^{\circ} \mathrm{C}\right)$ & -85 & -85 & -120 \\
\hline Crystal dimensions (mm) & $0.45 \times 0.6 \times 0.7$ & $0.4 \times 0.4 \times 0.4$ & $0.4 \times 0.5 \times 0.6$ \\
\hline Space group & $C 2 / c$ & $P 4_{1} 2_{1} 2$ & $P 2_{1} / n$ \\
\hline$a(\mathrm{pm})$ & $1801.8(6)$ & $1330.0(3)$ & $1128.0(2)$ \\
\hline$b(\mathrm{pm})$ & $1231.9(6)$ & - & $1377.2(2)$ \\
\hline$c(\mathrm{pm})$ & $1949.9(7)$ & $2179.7(2)$ & $1394.3(2)$ \\
\hline$\beta\left(^{\circ}\right)$ & $110.68(3)$ & - & $93.17(2)$ \\
\hline Cell volume $\left(\mathrm{nm}^{3}\right)$ & 4.05 & 3.86 & 2.16 \\
\hline Formula units per cell $Z$ & 4 & 4 & 2 \\
\hline$D_{c}\left(\mathrm{Mg} \mathrm{m}^{-3}\right)$ & 1.075 & 1.073 & 1.114 \\
\hline Absorp. coeff. $\mu\left(\mathrm{mm}^{-1}\right)$ & 0.27 & 0.23 & 0.26 \\
\hline Measured $2 \theta$-range $\left(^{\circ}\right)$ & $8-50$ & $8-45$ & $8-45$ \\
\hline Number of measured reflections & 4864 & 2620 & 2847 \\
\hline Number of unique reflections & 3540 & 2492 & 2812 \\
\hline Number of observed reflections & 2857 & 1720 & 2309 \\
\hline$F>p \sigma(F) ; p=$ & 3 & 3 & 3 \\
\hline $\boldsymbol{R}$ & 0.058 & 0.076 & 0.044 \\
\hline $\boldsymbol{R}_{\mathrm{w}}$ & 0.067 & 0.063 & 0.048 \\
\hline Goodness of fit & 2.24 & 1.44 & 1.62 \\
\hline Weighting factor $\boldsymbol{g}$ & 0.0003 & 0.0004 & 0.0003 \\
\hline Refined parameter & 189 & 187 & 212 \\
\hline Data-to-parameter ratio & $15.1: 1$ & $9.2: 1$ & $10.9: 1$ \\
\hline Largest peak (e-nm $\left.{ }^{-3} \times 10^{2}\right)$ & 6.3 & 4.4 & 3.6 \\
\hline Largest hole $\left(e-\mathrm{nm}^{-3} \times 10^{2}\right)$ & 4.4 & 4.5 & 2.4 \\
\hline$\eta$-refinement & - & $1.2(6)$ & - \\
\hline
\end{tabular}


Table 2

Selected bond lengths (pm) and angles $\left(^{\circ}\right)$ for 1-3

\begin{tabular}{llll}
\hline$R$ & 1 & 2 & 3 \\
\cline { 2 - 4 } & $\mathrm{SiMe}_{3}$ & ${ }^{\mathrm{B} u}$ & $\mathrm{SiMe}_{3}$ \\
\hline Li(1)-N(1) & $199.4(3)$ & $198.3(8)$ & $202.2(5)$ \\
Li(1)-N(2) & $224.5(5)$ & $223.4(13)$ & $239.3(5)$ \\
Li(1)-N(2a) & - & - & $205.4(5)$ \\
Li(2)-N(2) & $203.3(5)$ & $200.5(11)$ & - \\
Li(1)-O(1) & - & - & $197.4(5)$ \\
Li(2)-O(1) & $189.7(9)$ & $192.1(19)$ & - \\
S(1)-N(1) & $159.5(3)$ & $161.3(6)$ & $159.3(2)$ \\
S(1)-N(2) & $162.3(3)$ & $162.2(6)$ & $162.7(2)$ \\
S(1)-C & $180.8(4)$ & $182.6(8)$ & $180.3(3)$ \\
N(1)-S(1)-N(2) & $105.7(1)$ & $105.6(3)$ & $105.9(1)$ \\
N(1)-S(1)-C & $104.4(2)$ & $104.1(3)$ & $104.7(1)$ \\
N(2)-S(1)-C & $101.5(3)$ & $101.5(3)$ & $104.0(1)$ \\
\hline
\end{tabular}

Bis(lithium- $N, N^{\prime}$-bis(trimethylsilyl)-S-phenyl-sulfinimidamide-tetrahydrofuranate (3): Yield $7.2 \mathrm{~g} \mathrm{(98 \% ).}{ }^{1} \mathrm{H}$ NMR: $\delta=0.28\left(\mathrm{~s}, \mathrm{Si}\left(\mathrm{CH}_{3}\right)_{3}\right) ; 1.29(\mathrm{t}$, $\mathrm{O}\left(\mathrm{CH}_{2}\right)_{2}\left(\mathrm{CH}_{2}\right)_{2} ; 3.25\left(\mathrm{t}, \mathrm{O}\left(\mathrm{CH}_{2}\right)_{2}\left(\mathrm{CH}_{2}\right)_{2}\right) ; 7.0-8.0\left(\mathrm{~m}, \mathrm{C}_{6} \mathrm{H}_{5}\right) .{ }^{13} \mathrm{C} \mathrm{NMR}: \delta=2.72$

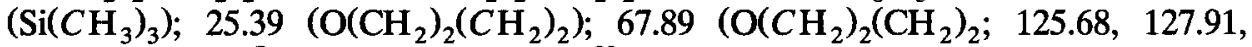
137.43, $\left(C_{6} \mathrm{H}_{5}\right) .{ }^{7} \mathrm{Li}$ NMR: $\delta=1.2(\mathrm{~s}) ;{ }^{29} \mathrm{Si}$ NMR: $\delta=-0.6(\mathrm{~s})$.

Table 3

Atomic coordinates $\left(\times 10^{4}\right)$ and equivalent isotropic displacement coefficients $\left(\AA^{2} \times 10^{3}\right)$ of 1

\begin{tabular}{|c|c|c|c|c|}
\hline & $x$ & $y$ & $z$ & $U_{\text {eq }}{ }^{a}$ \\
\hline$\overline{S(1)}$ & $1256(1)$ & $1726(1)$ & $3682(1)$ & $31(1)$ \\
\hline Si(1) & $826(1)$ & $-445(1)$ & $3922(1)$ & $35(1)$ \\
\hline $\mathrm{Si}(2)$ & $1721(1)$ & $2596(1)$ & $2558(1)$ & $43(1)$ \\
\hline $\mathrm{N}(1)$ & $585(2)$ & $818(2)$ & $3532(1)$ & $31(1)$ \\
\hline $\mathrm{N}(2)$ & $996(1)$ & $2471(2)$ & 2949(1) & $32(1)$ \\
\hline $\mathrm{Li}(1)$ & 0 & $1276(6)$ & 2500 & $37(3)$ \\
\hline $\mathrm{Li}(2)$ & 0 & $3380(6)$ & 2500 & $41(3)$ \\
\hline$C(1)$ & $-98(2)$ & $-1263(3)$ & $3553(2)$ & $52(1)$ \\
\hline$C(2)$ & $1169(3)$ & $-408(3)$ & $4941(2)$ & $61(2)$ \\
\hline$C(3)$ & $1633(3)$ & $-1101(3)$ & $3671(2)$ & $58(2)$ \\
\hline $\mathrm{C}(4)$ & $1364(2)$ & $3655(3)$ & $1828(2)$ & $58(2)$ \\
\hline$C(5)$ & $2695(2)$ & $3041(4)$ & $3210(2)$ & $70(2)$ \\
\hline$C(6)$ & $1859(3)$ & $1289(4)$ & 2141(3) & $78(2)$ \\
\hline$C(7)$ & $1077(2)$ & $2630(3)$ & $4336(2)$ & $37(1)$ \\
\hline$C(8)$ & $428(2)$ & $2519(3)$ & $4542(2)$ & $47(1)$ \\
\hline$C(9)$ & $304(3)$ & $3250(3)$ & $5034(2)$ & $62(2)$ \\
\hline$\alpha(10)$ & $844(3)$ & $4058(4)$ & $5332(2)$ & $71(2)$ \\
\hline$C(11)$ & $1500(3)$ & $4139(4)$ & $5148(3)$ & $80(2)$ \\
\hline C(12) & $1622(2)$ & $3430(3)$ & $4647(2)$ & $60(2)$ \\
\hline $\mathrm{O}$ & 0 & $4922(3)$ & 2500 & $80(2)$ \\
\hline$C(13)$ & $389(4)$ & $5471(5)$ & $3219(5)$ & $167(6)$ \\
\hline$C(14)$ & $1130(5)$ & $5791(6)$ & $3387(5)$ & $162(5)$ \\
\hline
\end{tabular}

${ }^{a}$ Equivalent isotropic $U$ defined as one third of the trace of the orthogonalized $U_{i j}$ tensor. 
Table 4

Atomic coordinates $\left(\times 10^{4}\right)$ and equivalent isotropic displacement coefficients $\left(\AA^{2} \times 10^{3}\right)$ of 2

\begin{tabular}{|c|c|c|c|c|}
\hline & $x$ & $y$ & $z$ & $U_{\mathrm{eq}}{ }^{a}$ \\
\hline$S(1)$ & $-856(1)$ & $1210(2)$ & $785(1)$ & $42(1)$ \\
\hline$C(1)$ & $-2122(6)$ & $1327(5)$ & $467(3)$ & 41(3) \\
\hline$C(2)$ & $-2898(6)$ & $907(6)$ & $771(4)$ & $54(3)$ \\
\hline$C(3)$ & $-3867(7)$ & $1024(7)$ & $558(5)$ & $70(4)$ \\
\hline$C(4)$ & $-4028(7)$ & $1564(7)$ & $33(5)$ & $72(4)$ \\
\hline$C(5)$ & $-3248(7)$ & $2002(7)$ & $-272(4)$ & $65(4)$ \\
\hline$C(6)$ & $-2284(6)$ & $1901(6)$ & $-49(4)$ & $50(3)$ \\
\hline $\mathrm{N}(1)$ & $-148(4)$ & $1744(4)$ & $281(3)$ & $44(2)$ \\
\hline $\mathrm{Si}(1)$ & $311(2)$ & 2935(2) & $375(1)$ & 53(1) \\
\hline$C(11)$ & $1156(7)$ & 3075(8) & $1029(4)$ & $79(4)$ \\
\hline$C(12)$ & $-696(7)$ & $3905(6)$ & $469(4)$ & $77(4)$ \\
\hline C(13) & $1008(8)$ & 3183(7) & $-344(4)$ & $88(4)$ \\
\hline $\operatorname{Li}(1)$ & $465(9)$ & $465(9)$ & $\mathbf{0}$ & $53(5)$ \\
\hline $\mathrm{N}(2)$ & $-655(4)$ & $13(4)$ & $712(3)$ & $38(2)$ \\
\hline$C(20)$ & $-258(5)$ & $-484(5)$ & $1288(3)$ & $36(3)$ \\
\hline$C(21)$ & $-980(6)$ & $-388(7)$ & $1827(3)$ & 68(4) \\
\hline$C(22)$ & $780(6)$ & $-18(7)$ & $1469(3)$ & $66(4)$ \\
\hline$C(23)$ & $-91(7)$ & $-1593(6)$ & $1122(4)$ & $66(4)$ \\
\hline $\mathrm{Li}(2)$ & $-907(9)$ & $-907(9)$ & 0 & $47(4)$ \\
\hline$O(1)$ & $-1929(4)$ & $-1929(4)$ & $\mathbf{0}$ & $51(2)$ \\
\hline$C(31)$ & $-2750(7)$ & $-1919(7)$ & $429(4)$ & $72(4)$ \\
\hline$C(32)$ & $-3702(8)$ & $-1716(10)$ & $124(5)$ & $110(6)$ \\
\hline
\end{tabular}

${ }^{a}$ Equivalent isotropic $U$ defined as one third of the trace of the orthogonalized $U_{i j}$ tensor.

Table 5

Atomic coordinates $\left(\times 10^{4}\right)$ and equivalent isotropic displacement coefficients $\left(\AA^{2} \times 10^{3}\right)$ of 3

\begin{tabular}{lllll}
\hline & $x$ & $y$ & $z$ & $U_{\text {eq }}{ }^{a}$ \\
\hline$S(1)$ & $6071(1)$ & $3668(1)$ & $6172(1)$ & $28(1)$ \\
C(1) & $5289(3)$ & $3910(2)$ & $7239(2)$ & $35(1)$ \\
C(2) & $5943(4)$ & $3824(3)$ & $8107(2)$ & $57(1)$ \\
C(3) & $5408(5)$ & $3970(4)$ & $8951(3)$ & $80(2)$ \\
C(4) & $4239(5)$ & $4179(3)$ & $8930(3)$ & $72(2)$ \\
C(5) & $3550(4)$ & $4279(3)$ & $8068(3)$ & $68(2)$ \\
C(6) & $4111(3)$ & $4125(3)$ & $7196(3)$ & $49(1)$ \\
N(1) & $5124(2)$ & $3131(2)$ & $5466(2)$ & $27(1)$ \\
Si(1) & $5087(1)$ & $1884(1)$ & $5494(1)$ & $33(1)$ \\
C(11) & $6622(3)$ & $1361(3)$ & $5587(3)$ & $65(2)$ \\
C(12) & $4273(3)$ & $1406(3)$ & $6522(3)$ & $60(2)$ \\
C(13) & $4296(4)$ & $1455(3)$ & $4376(3)$ & $74(2)$ \\
N(2) & $6262(2)$ & $4737(2)$ & $5708(2)$ & $25(1)$ \\
Si(2) & $7750(1)$ & $5022(1)$ & $5646(1)$ & $31(1)$ \\
C(21) & $7872(3)$ & $6349(2)$ & $5408(3)$ & $46(1)$ \\
C(22) & $8641(3)$ & $4763(3)$ & $6786(3)$ & $48(1)$ \\
C(23) & $8426(3)$ & $4322(3)$ & $4670(3)$ & $59(1)$ \\
Li(1) & $4953(4)$ & $4153(3)$ & $4427(3)$ & $30(2)$ \\
O(1) & $5248(2)$ & $3543(2)$ & $3182(1)$ & $37(1)$ \\
C(7) & $6319(3)$ & $3053(3)$ & $2942(3)$ & $48(1)$ \\
C(8) & $5985(3)$ & $2436(3)$ & $2079(3)$ & $59(1)$ \\
C(9) & $5029(4)$ & $3036(3)$ & $1575(3)$ & $66(2)$ \\
C(10) & $4368(3)$ & $3464(3)$ & $2395(2)$ & $47(1)$ \\
\hline
\end{tabular}

${ }^{a}$ Equivalent isotropic $U$ defined as one third of the trace of the orthogonalized $U_{i j}$ tensor. 
$X$-ray structure determinations of $1-3$

The structures of 1-3 were determined on a Stoe-Siemens-AED four-circle diffractometer with graphite-monochromated Mo- $K_{\alpha}$ radiation $(\lambda=71.073 \mathrm{pm})$ at $-85^{\circ} \mathrm{C}(1,2)$ and $-120^{\circ} \mathrm{C}(3)$. All structures were solved by direct methods [17] and refined by full-matrix least-squares methods, with all non-hydrogen atoms anisotropic. The hydrogen atoms were located by difference Fourier synthesis and refined using a riding model. Chemically equivalent hydrogen atoms were refined with the same isotropic displacement parameters. In all three structure determinations, a weighting scheme with $w^{-1}=\sigma^{2}(F)+g F^{2}$ was used. The factor $g$ for each structure can be found together with crystallographic data in Table 1. Selected bond length and angles are given in Table 2. Fractional coordinates for 1 are given in Table 3, by 2 in Table 4, and for 3 in Table 5.

Further details of the crystal structure analysis can be obtained from the Fachinformationszentrum Karlsruhe, Gesellschaft für wissenschaftlich-technische Information mbH, W-7514 Eggenstein-Leopoldshafen 2, Germany by quoting the deposit number CSD-56212, the authors, and the full title of the publication.

\section{Acknowledgment}

This work was supported by the Deutsche Forschungsgemeinschaft, Fonds der Chemischen Industrie and Stiftung Volkswagenwerk.

\section{References}

1 U. Wannagat and H. Kuckertz, Angew. Chem., 74 (1962) 1117.

2 O.J. Scherer and R. Schmitt, J. Organomet. Chem., 16 (1969) P11.

3 O.J. Scherer and R. Wies, Z. Naturforsch., Teil B, 25 (1970) 1486.

4 J. Kuyper and K. Vrieze, J. Chem. Soc., Chem. Commun., (1976) 64.

5 J. Kuyper, P.C. Keijzer and K. Vrieze, J. Organomet. Chem., 116 (1976) 1.

6 F. Pauer and D. Stalke, J. Organomet. Chem., 418 (1991) 127.

7 F. Pauer, J. Rocha and D. Stalke, J. Chem. Soc., Chem. Commun., (1991) 1477.

8 D. Stalke, U. Klingebiel and G.M. Sheldrick, J. Organomet. Chem., 344 (1988) 37.

9 D. Stalke, U. Klingebiel and G.M. Sheldrick, Chem. Ber., 121 (1988) 1457.

10 D.R. Armstrong, D. Barr, W. Clegg, R.E. Mulvey, D. Reed, R. Snaith and K. Wade, J. Chem. Soc., Chem. Commun., (1986) 869.

11 D. Seebach, W. Bauer, J. Hansen, T. Laube, W.B. Schweitzer and J.D. Dunitz, J. Chem. Soc., Chem. Commun., (1984) 853.

12 M. Veith, J. Böhnlein and V. Huch, Chem. Ber., 122 (1989) 811.

13 D.G. Anderson, H.E. Robertson, D.W.H. Rankin and J.D. Woollins, J. Chem. Soc., Dalton Trans., (1989) 859.

14 P.L. Rinaldi, J. Am. Chem. Soc., 105 (1983) 5167; C. Yu and G.C. Levy, J. Am. Chem. Soc., 106 (1984) 6533.

15 W. Bauer, T. Clark and P.v.R. Schleyer, J. Am. Chem. Soc., 109 (1987) 970.

16 W. Bauer and P.v.R. Schleyer, Magn. Reson. Chem., 26 (1988) 827.

17 SHELXTL PLUS, G.M. Sheldrick, Universität Göttingen. 